\title{
THE ROLE OF GROUNDWATER IN WATER ALLOCATION ALONG THE JORDAN RIVER BASIN
}

\author{
ROLA QUBA'A, MUTASEM EL-FADEL, IBRAHIM ALAMEDDINE \& MAJDI ABOU NAJM \\ Department of Civil \& Environmental Engineering, Faculty of Engineering \& Architecture, \\ American University of Beirut, Lebanon
}

\begin{abstract}
Water allocation along transboundary rivers invariably ignores the contribution of groundwater in the allocation process of shared water resources. This paper presents a first effort at examining the impact of groundwater on water allocation along the Jordan River Basin (JRB). The sensitivity of allocation is quantified through the assessment of scenarios that use weight factors commonly advocated towards equitable water allocation. In the absence of established quantification of groundwater resources, the study derived estimates groundwater safe yield within the basin. It then attempted to quantify international water law factors to evaluate reasonable shares for the basin's riparian countries by accounting for both surface and ground water resources. While existing water allocation patterns in the basin are still skewed compared to allocations based on international water law, consideration of groundwater usage is perceived to provide more realistic presentation of water quantities available for integrated river basin management as an ultimate goal of potential water agreements. We argue that relying on surface water abstractions only can bias perceived inequities by riparians and that consideration that both ground and surface water abstractions provide a more realistic basis. Agreements over transboundary water necessitate the improvement of groundwater characterization and the development of a clear understanding of this resource including potential lateral flows and interconnectedness between aquifers within the basin.
\end{abstract}

Keywords: transboundary water, groundwater resources, Jordan river.

\section{INTRODUCTION}

Worldwide, there are 263 transboundary river and lake basins accounting for around $60 \%$ of global freshwater [1]. Of those, around $60 \%$ lack any type of cooperative management framework [2]. In this context, the management of transboundary rivers is often complex due to disagreements over water allocations, water flows, riparian's contribution to that flow, historic uses, and future demands associated with social, ecological, and economic needs of each riparian [3]. One approach for defining transboundary water rights is by relying on criteria advocated in international water laws (Table 1) that regulate the use of transboundary water under the principle of reasonable and equitable sharing among riparians [4].

While the criteria apply equally to groundwater aquifers that connect hydrologically to surface water [5], groundwater has often been neglected in water allocation schemes. In this context, the Jordan River Basin (JRB), whose riparians include Israel, Jordan, Lebanon, Palestinian Authority, and Syria, represents a case where historically several water allocation plans were proposed, towards realizing a formal agreement over the utilization of its water resources. Yet, these plans considered only surface water resources and targeted mostly agricultural development [6]. More recent JRB related studies that examined water allocation based on international water law criteria (Table 1) and integrated water resources management also considered only surface water [5], [7]-[10]. This approach may result in distortions in water allocation and a potential for perceived inequities amongst riparians. In reality, groundwater resources within the basin are believed to play a critical yet unexplored role [11]. Hence, this study examines for the first time the undisclosed influence of groundwater resources on water allocation within the JRB and develops a water allocation 
Table 1: International law criteria for water sharing [7], [8].

\begin{tabular}{|l|l|}
\hline Criteria & Definition \\
\hline F1 & Basin geography including the extent of the drainage area in the territory of each riparian. \\
\hline F2 & Hydrology of the basin, including in particular the contribution of water by each riparian. \\
\hline F3 & Climate affecting the basin. \\
\hline F4 & Existing and potential utilization of the waters of the basin. \\
\hline F5 & Economic needs of each riparian. \\
\hline F6 & Social needs of each riparian. \\
\hline F7 & Population dependent on the waters of the basin in each basin state. \\
\hline F8 & Costs of alternative means of satisfying the water needs of riparians. \\
\hline F9 & Availability of other water resources in the basin. \\
\hline F10 & $\begin{array}{l}\text { Degree to which the needs of a riparian may be satisfied without causing appreciable } \\
\text { harm and substantial injury to a co-riparian. }\end{array}$ \\
\hline
\end{tabular}

scheme using international water law criteria coupled with a sensitivity analysis reflecting riparians reported perspectives on water allocation. The study outlines the approach adopted for estimating the groundwater resources and quantifying the international water law factors under two conditions: 1) accounting for surface water only, and 2) accounting for both surface and groundwater resources. A scenario analysis was conducted by varying factors' weights to define water allocation schemes. The results are then discussed in terms of significant criteria for enhancing allocation shares for each riparian, and evaluating the impact of accounting for groundwater resources on the allocation.

\section{METHODOLOGY}

\subsection{JRB groundwater resources}

In the absence of established quantification of groundwater resources for the JRB, the study presents a first attempt at deriving an estimate of available groundwater safe yields based on literature reported information (Fig. 1 and Table 2). For this purpose, several major assumptions were adopted: 1) aquifers are disconnected to eliminate the effect of lateral flows and considering no groundwater is crossing political borders; 2) the groundwater safe yield considered as part of the JRB mimics the percentage of an aquifer's surface catchment area falling within the basin's boundaries. This implies that the proportion of an aquifer's safe yield belonging to the basin is assumed to be proportional to the percentage of the aquifer's surface catchment area available within the basin's boundaries. As such, aquifers within the basin's boundaries were identified along with their reported annual safe yields. The percentage of the surface catchment area of each aquifer was then estimated using GIS delineated catchment boundaries (Fig. 1). The groundwater safe yield of the basin is then estimated by summing the product of each aquifer safe yield by the percentage of the aquifer's catchment area lying within the basin's boundaries.

This approach is associated with several limitations. First, interconnectedness may exist between aquifers and the approach cannot differentiate between water from direct recharge over an aquifer's surface catchment area or from lateral flows through other aquifers within or outside the basin. Second, groundwater safe yield proportion of the basin is estimated by area proportionality only, not by other criteria like population within the aquifer catchment. Third, part of the safe yield within an aquifer does not necessarily mimic the aquifer's surface area. Though ascertainment of the source of water flows and the interconnectedness of aquifers is imperative, the adopted assumptions allow for having a preliminary estimate that 


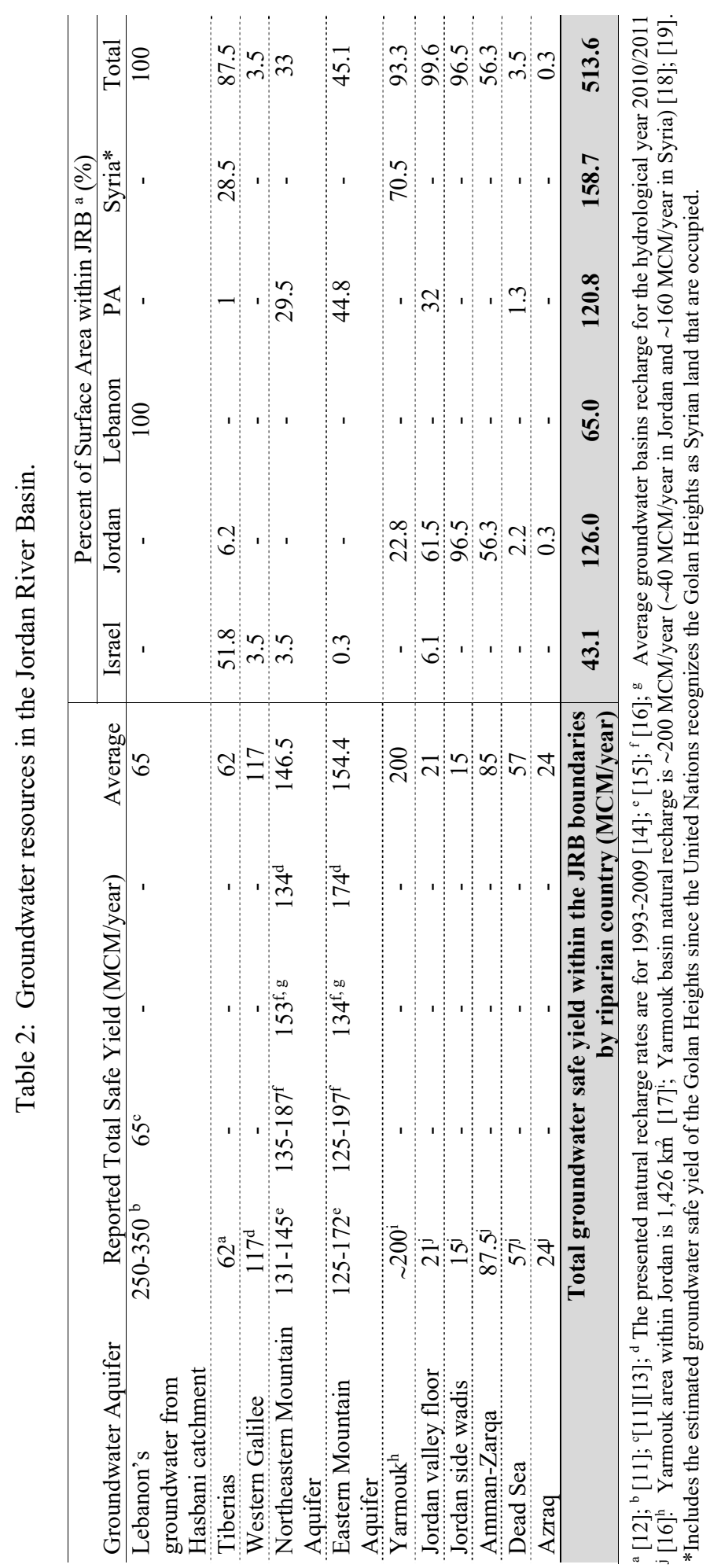




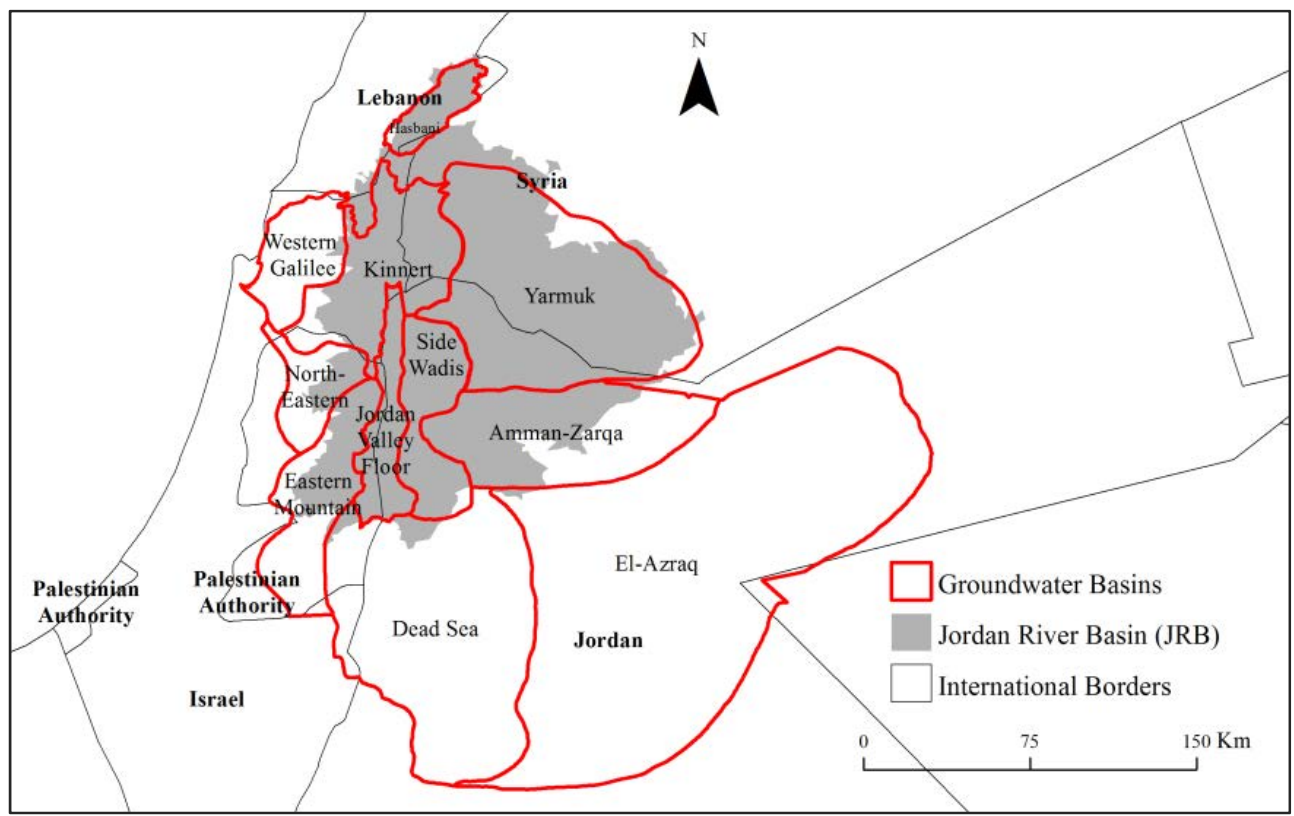

Figure 1: Groundwater basins within the JRB [12].

could be indicative of the significance of groundwater safe yield within the basin given the available information.

\subsection{Quantification of International water law factors}

The International water law factors were used to explore several scenarios whereby the factors were quantified (Table 3 ) in an effort to define water allocation schemes for the basin using two approaches: 1) considering only surface water resources; and 2) accounting for both surface and ground water resources. Adopting these two approaches influences the quantification of water flow (F2) and existing water utilization (F4). As such, these two factors were quantified twice. Once as F2(a) and F4(a) where water flows and utilization considered only surface water resources, and the second time as F2(b) and F4(b) which are quantified based on groundwater resources estimate and utilization. For the first approach of allocation based on surface water resources, the F2(a) and F4(a) were used. For the second approach, the sum of F2(a \& b) and the sum of F4(a \& b) were used.

\subsection{Derivation of country scores for quantified criteria}

For each factor under the two approaches of water allocation, country scores were derived as a percentage contribution to each riparian country, as expressed in eqn (1).

$$
F_{i, j}=\frac{X_{i, j}}{\left(\Sigma_{i=1}^{n} X_{i, j}\right)} * 100
$$

where $i=$ riparian country (from 1 to $\mathrm{n}=5$ ); $j=$ number of the allocation factor (from 1 to $\mathrm{m}=10) ; F_{i, j}=$ factor quantification score presented as the normalized score assigned to 
riparian $i$ with respect to factor $j(\%)$; and $X_{i, j}=$ value assigned to the $\mathrm{i}^{\text {th }}$ country with respect to the $\mathrm{j}^{\text {th }}$ factor.

The allocation factors were considered together as a whole and the weights assigned to each factor were based on their perceived relative importance in comparison to other factors. Initially, equal weights were assumed, suggesting no bias to any factor. Then, the weights were based on the average weights assigned by 90 international water experts (scenario 2 ), including representatives from the five riparian countries [9]. Given the likelihood that riparians will not agree on a common set of weights, 12 scenarios were tested, assuming different weighing structures. These "what if" scenarios start with the adoption of equal weights to all factors, followed with assigning higher weights to certain factors favoured by each riparian to shed light on the minimum and maximum allocation for all riparians from their perspective under various scenarios. This approach reflects also a one-factor-at-a-time (OFAT) sensitivity analysis to quantify the impact of each factor on the allocation scheme. A weight of 0.3 was assigned to a single factor (in an attempt to magnify its relative importance) and the remaining weight of 0.7 was divided equally amongst the remaining nine factors (scenarios 3-12). Changes in water allocation due to the variation in the weighing factors were then quantified. The overall allocation score for each riparian was calculated using eqn (2).

$$
S_{i}=\frac{\left(\sum_{j=1}^{m} F_{i, j} * W_{j}\right)}{\left(\sum_{i=1}^{n} \Sigma_{j=1}^{m} F_{i, j} * W_{j}\right)} * 100
$$

where $S_{i}=$ normalized allocation score for $i^{\text {th }}$ riparian ( 0 and 100 percent $)$; and $W_{j}=$ weight assigned to $j^{\text {th }}$ factor with $\sum_{1}^{j} W_{j}=1$.

\section{RESULTS AND DISCUSSION}

\subsection{Estimated groundwater resources}

The groundwater aquifers within the JRB are depicted in Fig. 1 with corresponding surface area identified within the basin's boundaries and reported safe yields presented in Table 2. In the Upper JRB, the steady flowing core of the Hasbani, Banias and Liddan rivers reflect groundwater-fed "base flows" with the bulk of the base flow for the Liddan River (241-249 MCM/year) originating from Lebanon and Syria [11], [20]. The karstic limestone geology of the area supports the notion of an intimate connection between groundwater and surface flows as well as the presence of fractured conduits that map across the international political borders of Israel-Lebanon or Israel-Syria. While the direction and flow rates of the groundwater are not monitored in Lebanon and Syria and are poorly monitored or reported in Israel, estimates of $250-350 \mathrm{MCM} /$ year of transboundary groundwater crossing from Lebanon to Israel have been reported implying a significant contribution to the total transboundary water flows in the Upper JRB [11]. Despite the uncertainty around these estimates, it can still be argued that recharge areas for major springs in the Upper JRB are connected to transboundary groundwater resources, where the entire recharge zone of the Liddan Springs lies in Lebanon and Syria [22]. In the Lower JRB, groundwater resources play a more prominent role whereby the Yarmouk aquifer and other groundwater basins exist within the boundaries of the Lower JRB (Fig. 1) including Kinneret/Tiberias aquifer (62 MCM/year), the side wadis along the eastern escarpment of the Jordan Valley $(\sim 15$ $\mathrm{MCM} /$ year), the Jordan Valley floor area ( 21 MCM/year), and the Amman-Zarqa basin (87.5 MCM/year) [19], [18]-[35]. In addition, there is the Mountain Aquifer, a transboundary aquifer west of the Jordan River extending over Israeli and the Palestinian territories. The 


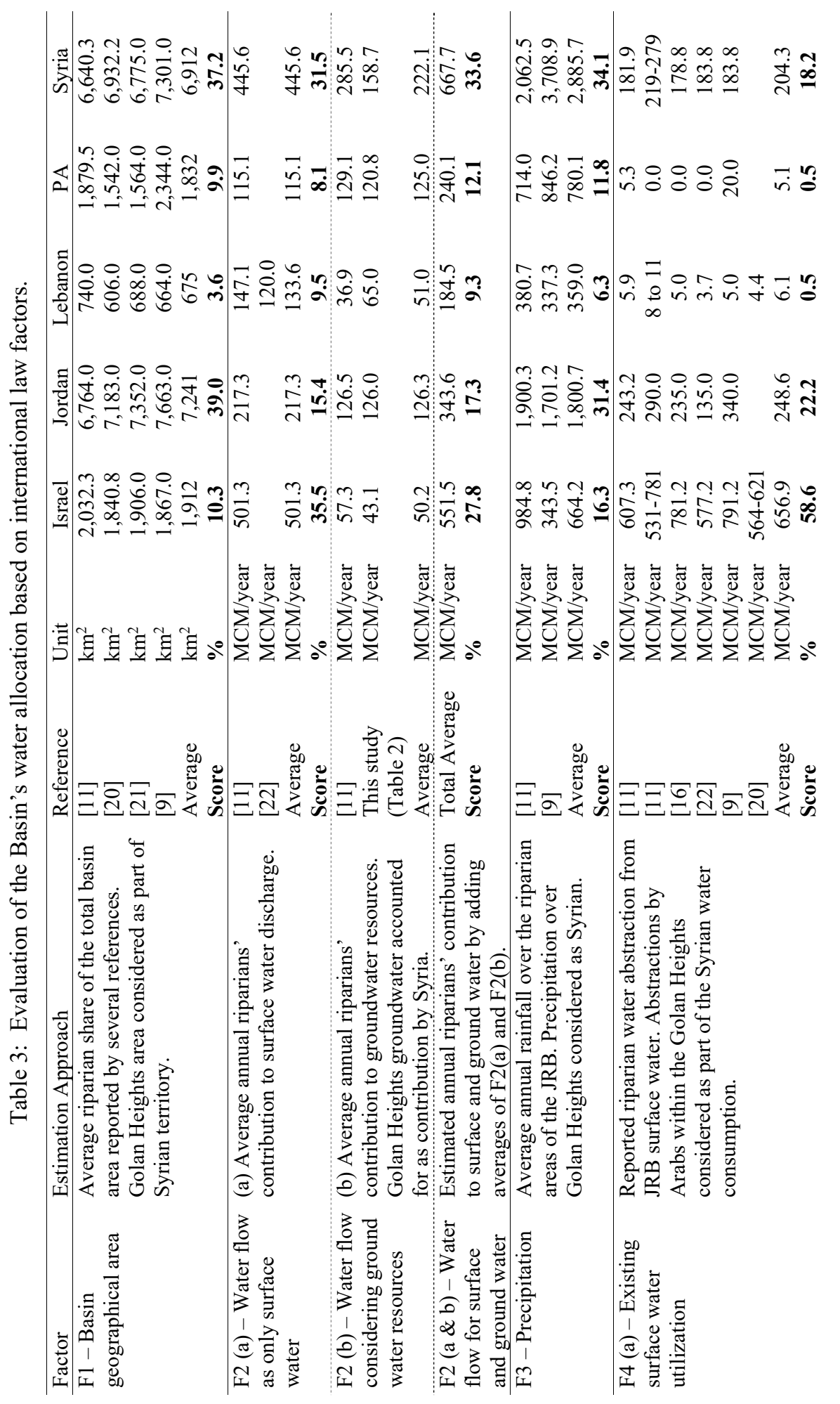




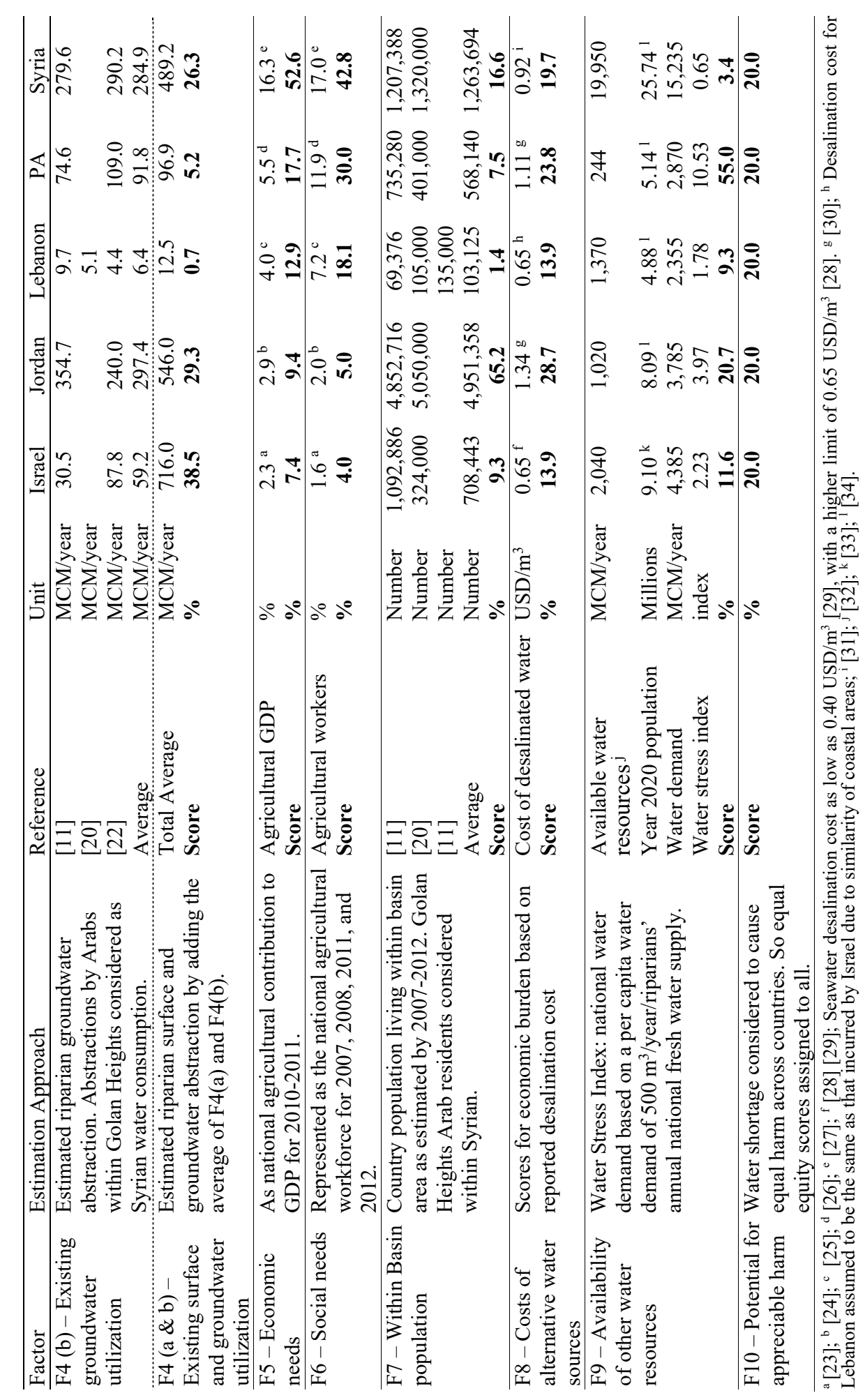


aquifer in its North-eastern basin is estimated at 130 to $145 \mathrm{MCM} /$ year, while flows in the Eastern basin range between 125-172 MCM/year [15], [34]. Currently, the Mountain Aquifer is the subject of an independent transboundary water sharing agreement ratified by Israelis and Palestinians. Only small portions of the western Galilee, El-Azraq and Dead Sea basins' surface areas appear to lie within the JRB.

The resulting estimated groundwater resources within the JRB by riparian country (Table 2) show that the greatest amount of groundwater seems to be available in Syria, Jordan, and the PA followed by Lebanon at $65 \mathrm{MCM} /$ year. These riparians contribute almost $87 \%$ of the JRB groundwater safe yield estimated at $513 \mathrm{MCM} /$ year.

Another estimate of groundwater resources within the JRB [13] exhibited similar results except for difference in estimated quantities for Lebanon and Syria. SIDA [13] considered around $29 \%$ and $9 \%$ of groundwater safe yield from Lebanon to be inflow to Israel and Golan Heights, respectively, and consequently estimated Lebanon's groundwater at only 37 MCM/year. On the other hand, SIDA [13] estimated Syria's groundwater at $255 \mathrm{MCM} / \mathrm{year}$ based on an interpretation of water abstraction rates cited in UN-ESCWA and BGR [20]. For Israel, Jordan, and the PA, the estimates are consistent mainly due to more readily available data about groundwater resources within these portions of the basin.

\subsection{Transboundary water allocations}

The scores of the quantified international water law allocation factors by riparian country reveal that 1) the highest percentage of the basin's catchment area are attributed to Jordan and Syria; 2) the highest percentage of surface water discharge into the basin is attributed to Israel followed by Syria and Jordan, while the highest percentage of surface and ground water discharge into the basin are attributed to Syria followed by Israel and Jordan; 3) Israel, followed by Jordan and Syria are the greatest users of the basin's surface and ground water resources; 4) the highest percentage of rainfall occurs in Syria and Jordan; 5) the highest within basin population and consequently the highest expected water demand among the basin's riparians are in Jordan followed by Syria; and 6) though Palestinians are entitled to a share in the basin's water, they are currently using $0.5 \%$ of its surface waters and $\sim 5 \%$ of its overall surface and ground water resources.

According to Table 4 and under the baseline scenario of equal weights, Israel's share in the JRB surface water is evaluated at $\sim 19 \%$, Jordan's $\sim 26 \%$, Lebanon's $10 \%$, the Palestinian Authority's $\sim 18 \%$, and Syria's $\sim 28 \%$. However, when considering both surface and ground water resources under the baseline scenario of equal weights, Israel's share becomes $\sim 15 \%$ and Syria's $\sim 30 \%$ while Jordan's, Lebanon's, and the Palestinian Authority's remain more or less the same (Table 4). The observed changes in shares is due to changes in contribution of each riparian to water discharge (F2) and to water utilization rate (F4). Moreover, considering both surface and ground water reduced the levels of perceived inequity albeit by relatively small ranges. For example, Israel's exceedance was reduced by $13.3 \%$ because groundwater within the Israeli portion of the JRB contributes small amounts compared to available surface water and Israel is abstracting the majority of the surface water. Though under scenario 1 of considering both ground and surface water Jordan appears to be close to exceeding its share by $\sim 5 \%$, this requires care in analysis as Jordan is known to be over abstracting from its groundwater resources and the sources of over abstracted quantities are not verified whether they belong to the JRB or not.

Under the scenario 2 (experts assigned weights), Israel's share in the JRB surface water is evaluated at $\sim 25 \%$, Jordan's $\sim 27 \%$, Lebanon's $8 \%$, the Palestinian Authority's $\sim 15 \%$, and 
Syria's $\sim 26 \%$. However, when considering both surface and ground water resources of the JRB, the shares become $\sim 19 \%$ for Israel, $\sim 28 \%$, Jordan's, $\sim 7 \%$ Lebanon's, $\sim 16 \%$ the Palestinian Authority's, and $\sim 30 \%$ Syria's (Table 4). Under scenario 2, considering both surface and ground water resulted in enhancing Israel's level of exceedance by $\sim 4 \%$ since the experts assigned weights tend to emphasize more the factors related to water flow (F2), precipitation (F3), and existing use (F4). For other riparians, similar trend as under the equal weights scenario was observed.

Overall, the allocations under the various scenarios and considerations (Table 4) indicate that irrespective of the assigned weights, if the international water law criteria were enforceable, then Israel would be considered to be exceeding its potential share given that the existing allocation pattern of Israel ( $\sim 59 \%$ of the JRB surface waters and $\sim 38 \%$ of surface and ground water supplies) cannot be attained. This is emphasized by the similar trends observed under scenario 1 (equal weights) and scenario 2 (average of experts assigned weights), where Israel continues to be over utilizing its potential share and the remaining riparians underutilizing theirs. Thus, the influence of groundwater mainly resulted in reducing Israel percentage share from 19-25\% range when considering surface water only to $15-19 \%$ of both surface and ground water resources. The remaining riparians shares were either enhanced or did not witness a considerable change (Lebanon). On the other hand, Lebanon's and the PA's should be using more of the basin's water resources given that they are greatly underutilizing their potential shares. The unobservable change for Lebanon's share when accounting for groundwater resources emphasizes that Lebanon is not exploiting its water supplies within its territories of the JRB.

Table 4: Water allocation when accounting for sources under equal factors weights.

\begin{tabular}{|c|c|c|c|c|c|c|}
\hline \multirow[b]{2}{*}{ Category } & \multirow[b]{2}{*}{ Condition } & Israel & Jordan & Lebanon & PA & Syria \\
\hline & & \multicolumn{5}{|c|}{ Percent $(\%)$} \\
\hline \multirow{6}{*}{$\begin{array}{l}\text { Surface } \\
\text { water* }\end{array}$} & Existing use & 58.6 & 22.2 & 0.5 & 0.5 & 18.2 \\
\hline & Equal weights (scenario 1) & 18.7 & 25.7 & 9.6 & 18.4 & 27.6 \\
\hline & $\begin{array}{l}\text { Average of experts assigned } \\
\text { weights (scenario 2) }\end{array}$ & 24.8 & 26.6 & 7.6 & 14.7 & 26.4 \\
\hline & $\begin{array}{l}30 \% \text { of weight assigned to } \\
\text { one factor (scenarios } 3 \text { to } \\
12 \text { ) }\end{array}$ & $15.4-27.6$ & $21.1-34.5$ & $7.6-11.9$ & $14.4-26.5$ & $22.2-33.2$ \\
\hline & $\begin{array}{l}\text { Over or underutilization } \\
\text { based on equal weights }\end{array}$ & +148.6 & -31.5 & -95.4 & -98.1 & -47.7 \\
\hline & $\begin{array}{l}\text { Over or underutilization } \\
\text { based on experts' weights }\end{array}$ & +87.4 & -33.8 & -94.2 & -97.6 & -45.2 \\
\hline \multirow{6}{*}{$\begin{array}{l}\text { Surface } \\
\text { and } \\
\text { ground } \\
\text { water** }\end{array}$} & Existing use & 38.5 & 29.3 & 0.7 & 5.2 & 26.3 \\
\hline & Equal weights (scenario 1) & 15.3 & 26.2 & 9.5 & 19.3 & 29.7 \\
\hline & $\begin{array}{l}\text { Average of experts assigned } \\
\text { weights (scenario 2) }\end{array}$ & 18.8 & 27.8 & 7.4 & 16.2 & 29.7 \\
\hline & $\begin{array}{l}30 \% \text { of weight assigned to } \\
\text { one factor (scenarios } 3 \text { to } \\
12 \text { ) }\end{array}$ & $12.8-20.5$ & $21.5-34.9$ & $7.7-11.8$ & $16.2-27.2$ & $23.8-34.8$ \\
\hline & $\begin{array}{l}\text { Over or underutilization } \\
\text { based on equal weights }\end{array}$ & +135.3 & +4.7 & -93.3 & -74.8 & -17.0 \\
\hline & $\begin{array}{l}\text { Over or underutilization } \\
\text { based on experts' weights }\end{array}$ & +91.9 & -1.2 & -91.5 & -70.0 & -17.2 \\
\hline
\end{tabular}

* Surface water estimated at $\sim 1,413 \mathrm{MCM} /$ year; ** Surface and groundwater estimated at $\sim 1,927 \mathrm{MCM} /$ year. 
Finally, it is imperative to emphasize that in the absence of a database that have the consensus of all riparian countries, estimations reported in this study are only indicative and may provide a starting point for policy discussions until a comprehensive database is agreed upon by riparians. This also raises the need for a dynamic water allocation based on percentages rather than volumes which can accommodate variations in available natural water supplies due to the potential impacts of climate change for instance.

\section{CONCLUSION}

The reasonable shares of riparian countries from the transboundary waters of the JRB were evaluated based on the international water law criteria with considerations to both surface and ground water resources. The results revealed that current allocation patterns in the JRB are skewed. According to the international law factors and while accounting for the combined surface and groundwater resources, Israel's percentage share of the JRB water resources may range between 12.8-20.5\%, Jordan's between $21.5-34.9 \%$, Lebanon's $7.7-11.8 \%$, the Palestinian Authority's 16.2-27.2\%, and Syria's 23.8-34.8\%. Accounting for groundwater resources reduced Israel's share by $2.6-7.1 \%$. Additional characterizations for groundwater resources within the basin are imperative to define relevant safe yields and potential lateral flows that may influence the distribution of reasonable water shares within the JRB.

\section{ACKNOWLEDGEMENT}

Special thanks are extended to Dar Al-Handasah (Shair \& Partners) for its support to the graduate programs at the American University of Beirut.

\section{REFERENCES}

[1] UN Water (United Nations Task Force on Transboundary Waters), Transboundary Waters: Sharing Benefits, Sharing Responsibilities, UN Office to Support the International Decade for Action 'Water for Life' 2005-2015: Zaragoza, Spain, 2008.

[2] WWDR4 (United Nations World Water Development Report 4), Managing water under uncertainty and risk, 2012, Online. unesdoc.unesco.org/images/0021/002154/ 215492e.pdf. Accessed on: 13 Apr. 2017.

[3] Atalan, N., Transboundary Rivers. In: P. Robbins (ed.), Encyclopedia of Environment and Society, SAGE Publications, Inc., pp. 1765-1767, 2007.

[4] Wolf, A.T., Shared Waters: Conflict and Cooperation. Annual Review of Environment and Resources, 32, pp. 241-269, 2007.

[5] Rieu-Clarke, A. et al., UN Watercourses Convention: User's Guide, IHP-HELP Centre for Water Law, University of Dundee, 2012.

[6] Phillips, D.J.H. et al., The Jordan River Basin: 2. Potential future allocations to the co-riparians. Water International, 32(1), pp. 39-62, 2007.

[7] Levner, E., Integrated risk-based management of water resources in the Jordan River Basin. In: B. Morel \& I. Linkov (eds), Environmental security and environmental management: The role of risk assessment, Springer: Netherlands, pp. 269-279, 2006.

[8] Salman, S.M.A., The Helsinki Rules, the UN Watercourses Convention and the Berlin Rules: Perspectives on international water law. International Journal of Water Resources Development, 23(4), pp. 625-640, 2007.

[9] Mimi, Z.A. \& Sawalhi, B., A decision tool for allocating the waters of the Jordan River Basin between all riparian parties. Water Resources Management, 17, pp. 447-461, 2003.

[10] Sawalhi, B.I. et al., Multi-criteria decision tool for allocating the waters of the Jordan Basin between all ripairans. Proceedings of the International Conference 
"Globalization and Water Resources Management: The changing value of water", AWRA/IWLRI-University of Dundee, 6-8 Aug. 2001.

[11] Zeitoun, M. et al., Hydro-political baseline of the Upper Jordan River, Association of Friends of Ibrahim Abd el Al: Beirut, Lebanon, 2012.

[12] Sbaih, M., Groundwater inventory in the Jordan River Basin, SIDA (2016) project's final workshop, 26 Aug., Amman, Jordan, 2016.

[13] SIDA (Swedish International Development Cooperation Agency), Towards concerted sharing: Development of a regional water economy model in the Jordan River Basin. American University of Beirut, AlQuds University, The Arab Center for the Studies of Arid zones and Dry lands, Jordan University of Science and Technology, and The Centre for World Food Studies, Final Workshop, 24-25 August, Amman, Jordan, 2016.

[14] Weinberger, G. et al., The Natural Water Resources between the Mediterranean Sea and the Jordan River, Israel Water Authority, 2012, Online. http://www.water.gov.il/ Hebrew/about-reshut-hamaim/The-Authority/FilesWatermanagement/water-reportMEDITERRANEAN-SEA-AND-THE-JORDAN.pdf. Accessed on: 13 Apr. 2017.

[15] El-Fadel, M. et al., The Israeli Palestinian Mountain Aquifer: A case study in ground water conflict resolution. Journal of Natural Resources \& Life Sciences Education, 30, pp. 50-61, 2001.

[16] PWA (Palestinian Water Authority). Annual status report on water resources, water supply, and wastewater in the Occupied State of Palestine for 2011, Palestine, 2012.

[17] Ta'any, R. et al., Evaluation of groundwater quality in the Yarmouk Basin, North Jordan. Journal of Environmental Hydrology, 15, p. 28, 2007.

[18] Rimawi, O., Personal communication with Prof. Omar Rimawi, University of Jordan, 2016.

[19] MWI (Jordan Ministry of Water and Irrigation), Jordan water sector: Facts and figures 2013, MWI: Jordan, 2013.

[20] UN-ESCWA \& BGR (United Nations Economic and Social Commission for Western Asia; Bundesanstalt für Geowissenschaften und Rohstoffe), Inventory of Shared Water Resources in Western Asia, Beirut, 2013.

[21] Comair, G.F. et al., Hydrology of the Jordan River Basin: Watershed delineation, precipitation and evapotranspiration. Water Resources Management, 2012. doi:10.1007/s11269-012-0144-8.

[22] AFIAL (Association of the Friends of Ibrahim Abd El Al), Legal Analysis of Transboundary Waters in the Upper Jordan River Basin, Association of the Friends of Ibrahim Abd El Al: Beirut, Lebanon, 91 p. and Annexes, 2014.

[23] ICBS (Israel Central Bureau of Statistics), Population Projections, 2015.

[24] Jordan Department of Statistics. Statistical Yearbook 2013, (64), Hashemite Kingdom of Jordan, Department of Statistics, 2013.

[25] Lebanon Central Administration for Statistics, Lebanese national accounts 2004-2011: Comments and tables, 2013, Online. www.cas.gov.lb/images/PDFs/National \%20Accounts/CAS_Lebanon_National_Accounts_2011_Comments_and_tables.pdf. Accessed on: 13 Apr. 2017.

[26] PCBS (Palestinian Central Bureau of Statistics), Statistical Yearbook of Palestine, 2012, Online. http://www.pcbs.gov.ps/Downloads/book194971.pdf. Accessed on: 13 Apr. 2017.

[27] SCBS (Syria Central Bureau of Statistics), Statistical abstract, 2011.

[28] Tenne, A., Sea Water Desalination in Israel: Planning, coping with difficulties, and economic aspects of long-term risks, State of Israel, Water authority, Desalination 
Division, 2010, Online. www.water.gov.il/Hebrew/Planning-and-Development/ Desalination/Documents/Desalination-in-Israel.pdf. Accessed on: 13 Apr. 2017.

[29] Elizur, Y., Over and drought: Why the end of Israel's water shortage is a secret, Haaretz, Online. http://www.haaretz.com/israel-news/1.570374. Accessed on: 13 Apr. 2017.

[30] Beyth, M., The Red Sea and the Mediterranean-Dead Sea canal project. Desalination, 214, pp. 365-371, 2007.

[31] Wardeh, S. et al., Desalination for Syria. In A. Hamdy \& R. Monti (eds), Food security under water scarcity in the Middle East: Problems and solutions, CIHEAM, (Série A. Séminaires Méditerranéens; no. 65): Bari, pp. 325-336, 2005.

[32] Keyzer, M.A. et al., Modeling the water economy of the Jordan River Basin, Centre for World Food Studies, Netherlands with a grant from Euro-Mediterranean Forum of Economic Institutes (FEMISE)/ Grant FEM21-02, 2004.

[33] ICBS (Israel Central Bureau of Statistics), Statistical abstract of Israel, 2013.

[34] UN (United Nations), World Population Prospects: The 2012 Revision (medium variant projections), 2012, Online. https://esa.un.org/unpd/wpp/publications/Files/ WPP2012_HIGHLIGHTS.pdf. Accessed on: 13 Apr. 2017.

[35] Rosenthal, E. \& Sabel, R., Water and Diplomacy in the Jordan River Basin. Israel Journal of Foreign Affairs, 3(2), pp. 95-115, 2009. 